\title{
Fintech, regtech, and financial development: evidence from China
}

\author{
Tadiwanashe Muganyi ${ }^{1}$, Linnan Yan' ${ }^{1}$, Yingkai Yin ${ }^{1}$, Huaping Sun ${ }^{2,3^{*}}$, Xiangbin Gong ${ }^{4}$ and \\ Farhad Taghizadeh-Hesary ${ }^{5^{*}}$ (1)
}

\author{
*Correspondence: \\ shp797@163.com; shp@ujs. \\ edu.cn; farhad@tsc.u-tokai. \\ ac.jp \\ ${ }^{2}$ School of Economics \\ and Management, Hebei \\ University of Technology, \\ Tianjin 300401, China \\ ${ }^{5}$ Tokai University, 4-1-1 \\ Kitakaname, Hiratsuka-shi, \\ Kanagawa 259-1292, Japan \\ Full list of author information \\ is available at the end of the \\ article
}

\begin{abstract}
This study investigates the influence of fintech on developments in China's financial sector across 290 cities and 31 provinces between 2011 and 2018. Using a two-stage least squares instrumental variable regression approach and correcting for cross-sectional dependency, simultaneity, and endogeneity of regressors, the results establish a positive link between fintech and financial development. Our findings show that fintech supports financial sector development by enhancing access (loans), depth (deposits), and savings within China's financial institutions. We also show that the emergence of fintech in the area of financial regulation (regulatory technology: regtech) can significantly improve financial development outcomes. Therefore, it is imperative for regulators to pursue policies that balance growth in the fintech sector while mitigating the associated risks. In addition, we use the difference-in-differences approach to show that policy measures such as interest rates liberalization also positively impacted financial development during the analysis period. In our conclusion, we suggest a policy framework for balanced fintech sector growth in developing countries.
\end{abstract}

Keywords: Fintech, Regtech, Financial development, China

JEL Classification: F30, G0, G29

\section{Introduction}

The term "fintech" refers to the application of new technologies and/or innovative business models that leverage existing information and communications technology in providing financial services (Nicoletti 2017). China is home to a number of leading fintech companies and has evolved into one of Asia's largest fintech hubs. The growth of China's fintech sector can be attributed to abundant capital; high internet penetration rates; a rising consumer class; and the use of innovative technologies such as big data analysis, artificial intelligence, and blockchain (Xiao et al. 2017; Zhou et al. 2018; Sun et al. 2020a, b). In addition, low credit card penetration, rigidities in the banking system, and growing consumption are accelerating fintech growth by providing opportunities for firms to offer new approaches that improve on the status quo (Insights 2019).

The relationship between fintech and financial development is a relatively new area of research that has been held back by data limitations. Financial development is a author(s) and the source, provide a link to the Creative Commons licence, and indicate if changes were made. The images or other third party material in this article are included in the article's Creative Commons licence, unless indicated otherwise in a credit line to the material. If material is not included in the article's Creative Commons licence and your intended use is not permitted by statutory regulation or exceeds the permitted use, you will need to obtain permission directly from the copyright holder. To view a copy of this licence, visit http:// creativecommons.org/licenses/by/4.0/. 
multidimensional concept encompassing four main dimensions: access, depth, efficiency in the provision of financial services, and stability (Sahay et al. 2015; Sun and Muganyi 2019; Sun et al. 2020a, b). This study employs proxy variables to represent three of these aspects of financial development. Intuitively, fintech growth is expected to support financial development by promoting financial inclusion and access (Leong et al. 2017; Jagtiani and Lemieux 2018; Cole et al. 2019). Although this is a valid point of view, adopting fintech also adds a new dimension of risk to financial markets.

China's fintech scene is highly concentrated among a small number of very large players. Ant Group, formerly Ant Financial, is the world's largest fintech company, and its wealth management services are used by over 600 million people (Tianhong 2019). China's fintech industry's rapid growth has put regulators in a position of playing catch up as they grapple with new dimensions of risk it represents. Traditional financial institutions are now working with fintech service providers to accelerate their own digital transformation strategies, focusing on offering more consumer centric financial services that cater to Millennial and Gen Z consumers (Sun et al. 2021).

A number of studies on fintech have focused on its potential as a catalyst for financial inclusion and access (Leong et al. 2017); however, to date there have been few empirical studies on the causal link between fintech and metrics of financial development. This study contributes to this subject matter in three novel ways. First, we explore how fintech influences various dimensions of financial development, namely, access, depth, and stability across 290 cities in China. Second, we shed light on how regtech can potentially enhance financial regulation effectiveness. Third, we highlight how active policy initiatives such as interest rate liberalization can improve financial development outcomes. The remainder of this study is structured as follows: "Fintech and financial development" section reviews the literature on fintech and financial development. "Data and methodology" section describes the base model, dataset, and econometric approaches used. "Results and discussions" section presents and discusses our key findings. "Conclusions and a policy framework for fintech regulation" section offers conclusions and policy recommendations on how fintech can support sustainable financial development in developing economies. Table 12 in the "Appendix A" provides definitions of the acronyms used herein.

\section{Fintech and financial development}

\section{China's fintech ecosystem}

Fintech can play an instrumental role in promoting financial and social inclusion in developing countries by reducing inefficiencies in resource allocation within the banking sector and creating economic opportunities that increase financial access and social development (Ding et al. 2018; Salampasis and Mention 2018). Fintech also provides access to financial services for market segments that do not meet the financing threshold of large commercial banks (Makina 2019). In China, fintech enhances credit supply to small and medium enterprises and provides an alternative to small banks (Sheng 2020).

By leveraging advanced technologies such as big data, artificial intelligence, biometrics, and blockchain, fintech companies aim to provide financial services that are more personalized, convenient, and consumer centric than what traditional providers offer (Ansari and Krop 2012; Christensen 2016; Drasch et al. 2018). The availability of venture 
capital has made it possible for fintech service providers to expand the scope of their services and grow at a remarkable pace (Haddad and Hornuf 2018). The rapid rise of fintech has expedited the digitalization of traditional banks. By working with fintech companies, traditional banks can offer greater convenience to their consumers (Drummer et al. 2016). Traditional banks are widely adopting fintech technologies, such as biometrics for customer authentication to enhance efficiency and security (Goode 2018). This trend of investing in fintech is expected to help traditional banks become more appealing to modern, tech-savvy consumers (PWC 2019).

According to Anagnostopoulos (2018), fintech innovations help to maintain banking system stability, and regulatory fintech (regtech) applications can lead to a more efficient, stable, and secure financial service environment. Regtech helps to improve stability in financial systems by reducing risks associated with digital financial services. The emergence of regtech also accelerates the transition to a new regulatory system for financial services (Zhou et al. 2018). While fintech does present several risks to financial systems, it can also be used to mitigate these risks (Lee and Shin 2018). This presents a tradeoff for regulators who seek to promote fintech sector growth without negatively impacting consumer confidence (Mahoney 2019).

According to Ernst and Young's (2019) global fintech adoption report, China has one of the world's highest fintech adoption rates at $87 \%$, whereas fintech products that focus on mobile payments and transfers in the country have a 95\% adoption rate. Accenture (2018) estimated the value of total investment in China's fintech industry to be USD 25.5 billion as of 2018, accounting for over $46 \%$ of global fintech investment. China's largest tech companies are entering the fintech sector, providing various financial intelligence solutions and other digital financial services. For global fintech investors, China appears to provide the right market conditions and regulatory frameworks to pilot fintech ventures (Wharton 2019).

The growth of the fintech industry depends on how the actors within the ecosystem interact (Diemers et al. 2015). The fintech ecosystem can be split into five main stakeholder groups: fintech start-ups, tech developers, financial consumers, incumbent financial institutions, and regulators. How these stakeholders interact is critical to the growth and stability of the fintech industry. Table 1 highlights these key drivers of fintech growth in China.

\section{Fintech and financial development nexus}

Financial development is a difficult concept to measure (Levine 2005). A large proportion of the empirical work on the subject approximates financial development using the ratio of private credit to GDP. However, this approach does not capture the concept's multidimensional nature (Svirydzenka 2016). The World Bank uses several indexes to gauge financial development at the national level; however, researchers are still grappling with defining its various dimensions and how to measure them. Still, it is generally acknowledged that financial development is intricately linked to economic growth, enhances the rate of capital accumulation, and increases economic efficiency in resource allocation (Dobson and Westland 2018). Financial development also plays a critical role 
Table 1 Drivers of fintech sector growth. Source: Authors' compilation

\begin{tabular}{|c|c|}
\hline Driver & Aspects \\
\hline Technology & $\begin{array}{l}\text { Rapid adoption of emerging technologies in financial services: } \\
\text { Big data analytics, artificial intelligence, cloud and edge computing, blockchain, } \\
\text { natural language processing, information gathering, advanced analytics, biomet- } \\
\text { rics, mobile computing, internet of things (IOT), augmented reality, } 5 \mathrm{G}\end{array}$ \\
\hline Funding & $\begin{array}{l}\text { Readily available venture capital and other forms of funding for innovative fintech } \\
\text { start-ups. China is Asia's top fintech hub: VC and PE funding }\end{array}$ \\
\hline Consumer base shifts & $\begin{array}{l}\text { Chinese consumers now expect more convenience from financial service provid- } \\
\text { ers: personalized financial services, mobile and situational finance, digital conveni- } \\
\text { ence, rising consumer class needs, young tech-savvy millennials }\end{array}$ \\
\hline Regulation & $\begin{array}{l}\text { Stricter regulation on fintech industry is now promoting quality growth. Fintech } \\
\text { enterprises that meet real consumer needs are thriving in a more regulated envi- } \\
\text { ronment }\end{array}$ \\
\hline Financial service integration & $\begin{array}{l}\text { To offer more integrated financial services, traditional financial institutions are now } \\
\text { investing in new fintech subsidiaries or partnering with other independent fintech } \\
\text { providers }\end{array}$ \\
\hline Talent & $\begin{array}{l}\text { China's investment in tech-related disciplines and the return of foreign-educated } \\
\text { talents has also contributed to the rapid rise of the fintech industry }\end{array}$ \\
\hline
\end{tabular}

in lowering the volatility of consumption, investment growth, and economic output (Dabla-Norris and Srivisal 2013).

China's entry into the World Trade Organization in 2001 produced a surge in export-led growth for the country. Various institutional reforms were enacted to foster a more market-based financial industry that would further promote economic growth, although the key players were state-owned financial institutions (Hasan et al. 2009). Financial development in China has also been associated with positive socioeconomic outcomes focused on economic sustainability and reducing wealth inequality (Zhang et al. 2015). Furthermore, financial development is expected to support so-called green developments in China's cities and sustainability initiatives (Yin et al. 2019; Yuan et al. 2019; Muganyi et al. 2021).

However, Wang et al. (2015) concluded that financial development had no significant impact on growth in primary or secondary industries in China between 1978 and 2013. The conflicting research outcomes with respect to the role of financial development in the Chinese economy can in part be attributed to complexities in measurement. China's financial institutions have grown significantly in the past decade, and the country has become a global force in terms of financial market development (Min et al. 2018). The World Bank (2018) concludes that although financial development in China has been rapid, it remains incomplete. There is a need to prioritize effective financial regulatory practices to ensure it's sustainable growth.

The emergence of fintech presents a new set of opportunities and challenges for financial systems globally. Fintech's role in China's financial development is still unclear, and this study seeks to provide insights into how these two concepts are intricately linked. Figure 1 explores this nexus and forms the basis for two of our research hypotheses.

On the basis of the aforementioned theoretical analysis, we formulate the following hypotheses: 


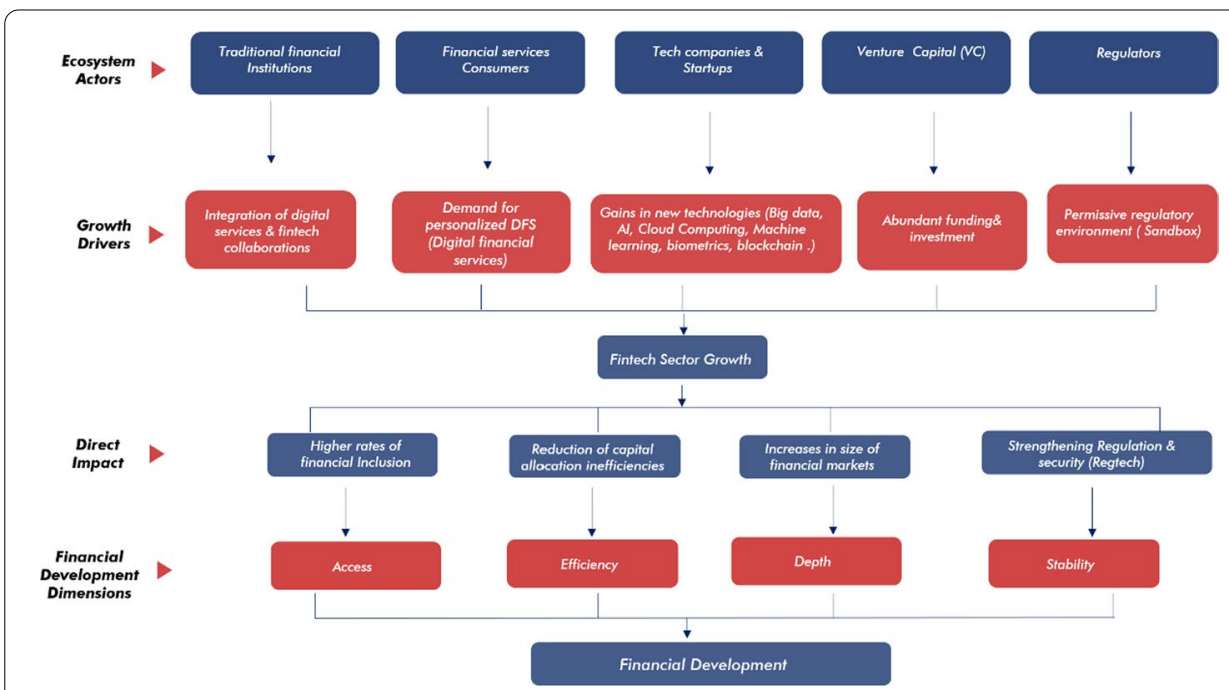

Fig. 1 Fintech and financial development nexus

I. Fintech has a positive impact on financial development with respect to access, depth, and stability.

II. Regtech significantly improves financial development outcomes.

\section{Interest rate liberalization and financial development}

Interest rate liberalization refers to a process whereby regulators cede some control over setting interests to market forces. For a considerable period, regulators in China have tightly controlled interest rates in the country's financial markets. This changed in July 2013 as regulators eliminated minimum lending rates, affording financial institutions greater autonomy in determining lending rates based on market forces. This marked the beginning of a new period of transition within China's banking industry (Jian and $\mathrm{Hu} 2020$ ), and more policies that aim to promote interest rate liberalization and greater financial openness are gradually being implemented. As part of this transition, fintech services such as money market mutual funds that promote interest rate liberalization are emerging (Li et al. 2019).

Financial liberalization in China is expected to promote economic growth and financial industry stability (Huang and Ji 2017), partly by reducing shadow banking practices such as tax avoidance and by easing credit constraints (Gopalan and Sasidharan 2020; Jiang et al. 2020). By speeding up the pace of financial liberalization, China seeks to avoid the "middle-income trap" and promote sustainable economic growth (Yiping et al. 2014). Financial liberalization also significantly reduces the likelihood of banking crises, thereby promoting stable financial development (Lee et al. 2016).

Based on the reviewed literature, we formulate our third hypothesis:

III. Interest rate liberalization has a positive impact on financial development in China. 


\section{Data and methodology}

\section{Base model}

This study uses panel data from 290 Chinese cities and 31 provinces for the period from 2011 to 2018. Similar empirical studies have found that financial development indicators are best predicted using lagged independent and control variables (Ryan et al. 2014; Li et al. 2016; Berger et al. 2017; Sheng 2020). To investigate the influence of fintech and regtech on financial development, we use the following base model.

$$
\begin{aligned}
F D_{i, t}= & \alpha_{0}+\alpha_{1} \text { Fintech }_{i, t-1}+\alpha_{2} \text { Finreg }_{i, t-1}+\alpha_{3} \text { Fintech }_{i, t-1} \times \text { Finreg }_{i, t-1} \\
& +\alpha_{c} \text { Control }_{i, t-1}+\eta_{t}+\lambda_{i}+\varepsilon_{i, t}
\end{aligned}
$$

where $\alpha_{i, s}$ are model parameters and $i$ and $t$ denote the city and year, respectively. The dependent variable $F D_{i, t}$ is the financial development indicator for city $i$ in year $t$. Measuring financial development comprehensively is challenging (Akçay 2019); here, we adopt a multidimensional approach to offer a complete analysis of how the predictor variables influence specific aspects of financial development by splitting it into three dimensions, namely, access, depth, and stability, represented by different proxy variables $F D_{(D) i, t}, F D_{(A) i, t}$ and $F D_{(S) i, t} F D_{(D)}$ represents the depth dimension of financial development, approximated by the level of financial institutions' deposits in each city. Similarly, $F D_{(A)}$ represents the access dimension using financial institution loan balances as a proxy. The stability dimension, denoted by $F D_{(S)}$, is measured by the level of rural and urban savings.

The level of fintech development in each city is denoted by Fintech, and Finreg represents expenditures on financial regulation. The interaction term Fintech $h_{i, t-1} \times$ Finreg $_{i, t-1}$ captures the deployment of fintech in the financial regulation arena and represents regtech in our base model. Control variables that influence financial development capture the level of economic activity, industrialization, and financial openness in each city (Rajan and Zingales 2003; Shahbaz et al. 2017). To control for the degree of economic activity and the size of financial markets, we use GDP per capita, denoted by GDPpc. Financial openness (FOP) is defined as foreign investment, and industrialization $(I N D)$ is measured as the proportion of value-added secondary industries to GDP. Our estimation equation is given as follows.

$$
\begin{aligned}
F D_{\mathrm{i}, \mathrm{t}}= & \alpha_{0}+\alpha_{1} \text { Fintech }_{i, t-1}+\alpha_{2} \text { Finreg }_{i, t-1}+\alpha_{3} \text { Fintech }_{i, t-1} \times \text { Finreg }_{i, t-1} \\
& +\alpha_{4} \text { GDPpc }_{i, t-1}+\alpha_{5} \text { FOP }_{i, t-1}+\alpha_{6} I N D_{i, t-1}+\eta_{t}+\lambda_{i}+\varepsilon_{i, t}
\end{aligned}
$$

To analyze how the interest rate liberalization policy introduced in 2013 has impacted China's financial development, we use a difference-in-differences (D-I-D) estimator. The D-I-D approach is widely applied in policy analysis research as it controls for both observable and unobservable factors that are constant over time. We employ the model as specified as follows.

$$
F D_{i, t}=\alpha_{0}+\alpha_{1} I R L_{i, t}+\alpha_{c} \operatorname{Control}_{i, t}+\eta_{t}+\lambda_{i}+\varepsilon_{i, t}
$$

where the dependent variable $F D_{\mathrm{i}, \mathrm{t}}$ encompasses the three dimensions of financial development, depth, access, and stability. The treatment effect or interest liberalization policy intervention variable $I R L_{i, t}$ takes a value of 1 after 2013 and 0 before the intervention. Individual and time dummy variables are represented by $\lambda_{i}$ and $\eta_{t}$, respectively. 


\section{Data}

The most comprehensive measure of fintech development in China is the Peking University Digital Financial Inclusion Index (PKU-DFII), which captures various dimensions of fintech development including coverage breadth, usage depth, mobile payments, insurance, monetary funds, investment, credit, credit investigations, and level of digitization (Guo et al. 2019). We use the PKU-DFII as our main measure of fintech development, as it is currently the most complete dataset with respect to capturing China's rapid fintech development during the analysis period at the county, city and provincial levels.

Table 2 highlights the average characteristics and summary statistics for our dataset.

To generate missing values, we use the epolate function, where the value of $y$ for a given value of $x$ is calculated by using the closest points $\left(x_{0}, y_{0}\right)$ and $\left(x_{1}, y_{1}\right)$, where $y_{0}$ and $y_{1}$ are observed values, and $x_{0}<x<x_{1}$. The epolate function uses the following formula:

$$
y=\frac{y_{1}-y_{0}}{x_{1}-x_{0}}\left(x-x_{0}\right)+y_{0}
$$

In the case where multiple observations of $x_{0}$ have the same value, $y_{0}$ becomes the average of the corresponding $y$ values (Meijering 2002).

Table 2 Data characteristics and summary statistics

\begin{tabular}{|c|c|c|c|c|c|c|c|c|}
\hline Variable & Measurement & Source & Obs & Mean & SD & Min & Max & Expected Sign \\
\hline $\begin{array}{l}\text { Financial Depth } \\
\left(F D_{(D)}\right)\end{array}$ & $\begin{array}{l}\text { Financial institu- } \\
\text { tions deposit } \\
\text { balances (log) }\end{array}$ & $\begin{array}{l}\text { Wind Data } \\
\text { Service }\end{array}$ & 2,312 & 16.786 & 1.046 & 14.415 & 21.083 & Criterion 1 \\
\hline $\begin{array}{l}\text { Financial Access } \\
\left(F D_{(A)}\right)\end{array}$ & $\begin{array}{l}\text { Financial institu- } \\
\text { tions loans (log) }\end{array}$ & $\begin{array}{l}\text { Wind Data } \\
\text { Service }\end{array}$ & 2,312 & 16.351 & 1.143 & 11.974 & 20.380 & Criterion 2 \\
\hline $\begin{array}{l}\text { Financial Stability } \\
\left(F D_{(S)}\right)\end{array}$ & $\begin{array}{l}\text { Urban and rural } \\
\text { residents' savings } \\
\text { (log) }\end{array}$ & $\begin{array}{l}\text { Wind Data } \\
\text { Service }\end{array}$ & 2,312 & 16.186 & 0.906 & 13.684 & 19.517 & Criterion 3 \\
\hline $\begin{array}{l}\text { Fintech Index } \\
\text { (Fintech) }\end{array}$ & $\begin{array}{l}\text { The Peking } \\
\text { University- } \\
\text { Digital Financial } \\
\text { Inclusion Index } \\
\text { of China (log) }\end{array}$ & $\begin{array}{l}\text { Institute of } \\
\text { Digital Finance, } \\
\text { Peking Univer- } \\
\text { sity (2019) }\end{array}$ & 2,311 & 4.668 & 0.719 & 1.590 & 5.654 & + \\
\hline $\begin{array}{l}\text { Financial Regula- } \\
\text { tion (Finreg) }\end{array}$ & $\begin{array}{l}\text { Fiscal expendi- } \\
\text { ture on financial } \\
\text { regulatory mat- } \\
\text { ters (log) }\end{array}$ & $\begin{array}{l}\text { China City Statis- } \\
\text { tical Yearbook } \\
(2010-2018)\end{array}$ & 2,279 & 38.912 & 9.029 & 0 & 71.805 & \pm \\
\hline $\begin{array}{l}\text { GDP per capita } \\
\text { (GDPpc) }\end{array}$ & $\begin{array}{l}\text { GDP per capita } \\
\text { in RMB (log) }\end{array}$ & $\begin{array}{l}\text { China City Statis- } \\
\text { tical Yearbook } \\
(2010-2018)\end{array}$ & 2,311 & 10.577 & 0.597 & 8.576 & 13.056 & + \\
\hline $\begin{array}{l}\text { Financial Open- } \\
\text { ness } \\
(\text { FOP) }\end{array}$ & $\begin{array}{l}\text { Actual foreign } \\
\text { investment USD } \\
10,000(\log )\end{array}$ & $\begin{array}{l}\text { EPS Database } \\
(2019)\end{array}$ & 2,311 & 3.856 & 0.272 & 1.656 & 4.497 & \pm \\
\hline $\begin{array}{l}\text { Industrialization } \\
\text { (IND) }\end{array}$ & $\begin{array}{l}\text { Secondary } \\
\text { industry value } \\
\text { added as a \% of } \\
\text { GDP (log) }\end{array}$ & $\begin{array}{l}\text { EPS Database } \\
(2019)\end{array}$ & 2,242 & 9.970 & 2.053 & -7.272 & 15.336 & \pm \\
\hline $\begin{array}{l}\text { Mobile phone } \\
\text { users } \\
\text { (Mpu) }\end{array}$ & $\begin{array}{l}\text { Number of } \\
\text { mobile phone } \\
\text { users (log) }\end{array}$ & $\begin{array}{l}\text { EPS Database } \\
(2019)\end{array}$ & 2,311 & 5.716 & 0.787 & 3.354 & 8.313 & \pm \\
\hline
\end{tabular}




\section{Cross-sectional dependency}

Cross-sectional dependency is an essential issue in econometric analysis of panel datasets and, if not addressed, can lead to spurious parameter estimation and false inference (Sarafidis and Wansbeek 2011). Among the tests for cross-sectional dependency, the Breusch and Pagan (1980) LM statistic is one of the most widely used in economic literature.

The null and alternative hypotheses of interest can be stated as follows:

$$
\begin{aligned}
& H_{0}: \operatorname{Cov}\left(v_{i, t}, v_{j, t}\right)=0 \quad \text { for all } t \text { and all } i \neq j \\
& H_{a}: \operatorname{Cov}\left(v_{i, t}, v_{j, t}\right) \neq 0 \quad \text { for some } t \text { and some } i \neq j
\end{aligned}
$$

where $v_{i, t}$ denotes the component of the error term that may be cross-sectionally correlated. There are two specifications of the LM statistic. The first holds when $T \rightarrow \infty$ and $N$ is fixed.

$$
L M_{0}=T \sum_{i=1}^{N-1} \sum_{J=i+t}^{N} \hat{\rho}_{i j}^{2} \stackrel{d}{\longrightarrow} \chi_{N(N-1) / 2}^{2}
$$

When both and $T$ and $N$ are large, the Breusch and Pagan LM statistic has distorted size properties. To correct for this, Pesaran (2004) proposes a scaled variant that holds when $T \rightarrow \infty$ and $N \rightarrow \infty$, sequentially.

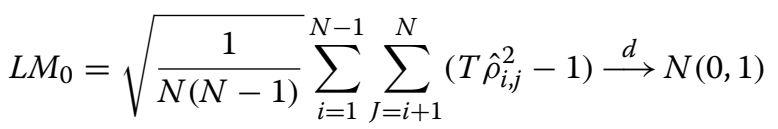

Pesaran and Yamagata (2008) suggest an extended version of the scaled LM statistic, termed the Pesaran CD statistic, that can be applied to a broad range of panel data models and holds for a fixed value of either $T$ or $N$.

$$
C D=\sqrt{\frac{2 T}{N(N-1)}}\left(\sum_{i=1}^{N-1} \sum_{J=i+1}^{N} \hat{\rho}_{i j}\right) \stackrel{d}{\longrightarrow} N(0,1)
$$

where $\hat{\rho}_{i j}$ is the sample estimate of the pairwise-correlation of the error term. The Pesaran CD statistic tends to a normal distribution when $T \rightarrow \infty$ and $N \rightarrow \infty$.

\section{Endogeneity and simultaneity}

Endogeneity is a serious challenge for social science research, as it leads to spurious correlations and inaccurate estimations of causal relationships. Sources of endogeneity include omitted variable bias, simultaneity, model misspecification, and selection bias (Wooldridge 2010; Zaefarian et al. 2017). Instrumental variable (IV) approaches are frequently used to address endogeneity in panel data analyses.

Because most consumer fintech platforms are used via mobile applications, we use the number of mobile users as the IV for fintech to address this variable's endogenous nature. Based on this, we assume that the fintech variable is endogenous as specified as follows. 


$$
\text { Fintech }_{i, t}=\pi_{0}+\pi_{1} M p u_{i, t}+\pi_{2} F I_{i, t-1}+\theta_{i, t}
$$

where $M p u_{i, t}$ represents the number of mobile phone users within a given city and $F I_{i, t-1}$ is the lagged value of the proxy variable for financial openness.

\section{Results and discussions}

\section{Test for cross-sectional dependency results}

Cross-sectional dependency is also a major issue in econometric analyses that use panel datasets. If not accounted for, it can lead to potentially spurious parameter estimation and false inferences (Sarafidis and Wansbeek 2011). Among the tests for cross-sectional dependency, the Breusch and Pagan (1980) LM statistic is one of the most widely used in economic research. After conducting a Hausman test and controlling for both city and year fixed effects, we test for weak cross-sectional dependency in all three models using the Pesaran (2014) CD test, which holds when $N>T$. Results are reported in Table 3.

The results of the Pesaran CD test reject the null hypothesis that the errors are weakly cross-sectionally dependent. There is strong cross-sectional dependence for all three models, which can be attributed to changes in financial regulatory policies and other shocks that affected the financial industry during the period studied.

To correct for cross-sectional dependence, we run our fixed effects model with standard errors clustered at the city level. Assuming Fintech $_{i, t}$ is endogenous as specified in Eq. (10), we run an IV regression and conduct post-estimation tests for endogeneity, under-identification, weak instruments, and overidentifying restrictions. Post-estimation tests indicate the relevance, explanatory strength, and validity of our employed instruments. Estimation results for both the FE and IV-two-stage least square (2SLS) approaches are shown in Table 4.

\section{Post-estimation test results}

Post-estimation test results confirm the validity of the instruments used in this study, with details discussed in the following subsections. These tests confirm that the IV regression estimation results are the most suitable for our model.

\section{Test for endogeneity}

The null hypothesis is rejected at the $1 \%$ level of significance, showing that in all three models the Fintech ${ }_{i, t}$ variable is endogenous and cannot be treated as an exogenous variable. Results of the endogeneity test are given in Table 5 .

Table 3 Pesaran CD test for weak cross-sectional dependence

\begin{tabular}{|c|c|c|c|c|c|}
\hline \multicolumn{2}{|c|}{ Model $1\left(F D_{(D)}\right)$} & \multicolumn{2}{|c|}{ Model $2\left(F D_{(A)}\right)$} & \multicolumn{2}{|c|}{ Model $3\left(F D_{(s)}\right)$} \\
\hline CD statistic & $P$ value & $C D$ statistic & $P$ value & CD statistic & $P$ value \\
\hline $170.408^{* * *}$ & 0.0000 & $191.208^{* * *}$ & 0.0000 & $207.533^{* * *}$ & 0.0000 \\
\hline
\end{tabular}

$H_{0}$ errors are weakly cross-sectionally dependent. $C D \sim N(0,1)$

***Significance at the $1 \%$ level 
Table 4 Influence of fintech on dimensions of financial development

\begin{tabular}{|c|c|c|c|c|c|c|}
\hline \multirow[t]{2}{*}{ Variables } & \multicolumn{2}{|c|}{$\begin{array}{l}\text { Model } 1 \\
\text { Criterion (FD(D) }\end{array}$} & \multicolumn{2}{|c|}{$\begin{array}{l}\text { Model } 2 \\
\text { Criterion (FD(A) }\end{array}$} & \multicolumn{2}{|c|}{$\begin{array}{l}\text { Model } 3 \\
\text { Criterion (FD(S) }\end{array}$} \\
\hline & $\mathrm{FE}$ & IV-2SLS & $\mathrm{FE}$ & IV-2SLS & $\mathrm{FE}$ & IV-2SLS \\
\hline Fintech $_{\mathrm{i}, \mathrm{t}-1}$ & $\begin{array}{l}0.184^{* * *} \\
(0.000)\end{array}$ & $\begin{array}{l}0.450^{* * *} \\
(0.000)\end{array}$ & $\begin{array}{l}0.306^{* * *} \\
(0.000)\end{array}$ & $\begin{array}{l}0.757^{* * *} \\
(0.000)\end{array}$ & $\begin{array}{l}0.241^{* * *} \\
(0.000)\end{array}$ & $\begin{array}{l}0.437^{* * *} \\
(0.000)\end{array}$ \\
\hline Finreg $_{\mathrm{i}, \mathrm{t}-1}$ & $\begin{array}{l}0.007 \\
(0.155)\end{array}$ & $\begin{array}{l}-0.040^{* * *} \\
(0.006)\end{array}$ & $\begin{array}{l}-0.009 \\
(0.219)\end{array}$ & $\begin{array}{l}-0.091^{* * *} \\
(0.001)\end{array}$ & $\begin{array}{l}0.003 \\
(0.564)\end{array}$ & $\begin{array}{l}-0.031^{* *} \\
(0.045)\end{array}$ \\
\hline Fintech $_{\mathrm{i}, \mathrm{t}-1} \times$ Finreg $_{\mathrm{i}, \mathrm{t}-1}$ & $\begin{array}{l}-0.005 \\
(0.854)\end{array}$ & $\begin{array}{l}0.223^{* * *} \\
(0.002)\end{array}$ & $\begin{array}{l}0.064^{*} \\
(0.084)\end{array}$ & $\begin{array}{l}0.455^{* * *} \\
(0.001)\end{array}$ & $\begin{array}{l}0.0004 \\
(0.988)\end{array}$ & $\begin{array}{l}0.163^{* *} \\
(0.028)\end{array}$ \\
\hline $\mathrm{GDPpc}_{i, t-1}$ & $\begin{array}{l}0.385^{* * *} \\
(0.000)\end{array}$ & $\begin{array}{l}0.275^{* * *} \\
(0.000)\end{array}$ & $\begin{array}{l}0.426^{* * *} \\
(0.000)\end{array}$ & $\begin{array}{l}0.246^{* * *} \\
(0.000)\end{array}$ & $\begin{array}{l}0.297^{* * *} \\
(0.000)\end{array}$ & $\begin{array}{l}0.211^{* * *} \\
(0.000)\end{array}$ \\
\hline$F O P_{i, t-1}$ & $\begin{array}{l}-0.014^{* * *} \\
(0.008)\end{array}$ & $\begin{array}{l}-0.012^{* * *} \\
(0.000)\end{array}$ & $\begin{array}{l}-0.011 \\
(0.150)\end{array}$ & $\begin{array}{l}-0.008 \\
(0.110)\end{array}$ & $\begin{array}{l}-0.016^{* * *} \\
(0.003)\end{array}$ & $\begin{array}{l}-0.014^{* * *} \\
(0.000)\end{array}$ \\
\hline$N D_{i, t-1}$ & $\begin{array}{l}-0.234^{* * *} \\
(0.000)\end{array}$ & $\begin{array}{l}-0.140^{* * *} \\
(0.000)\end{array}$ & $\begin{array}{l}-0.212^{* *} \\
(0.038)\end{array}$ & $\begin{array}{l}-0.046 \\
(0.429)\end{array}$ & $\begin{array}{l}-0.240^{* * *} \\
(0.000)\end{array}$ & $\begin{array}{l}-0.171^{* * *} \\
(0.000)\end{array}$ \\
\hline City FE & $\checkmark$ & $\checkmark$ & $\checkmark$ & $\checkmark$ & $\checkmark$ & $\checkmark$ \\
\hline Year FE & $\checkmark$ & $\checkmark$ & $\checkmark$ & $\checkmark$ & $\checkmark$ & $\checkmark$ \\
\hline Observations & 2,210 & 1932 & 2,210 & 1932 & 2,210 & 1932 \\
\hline F Statistic & $1181.94^{* * *}$ & $1462.74^{* * *}$ & $693.55^{* * *}$ & $574.25^{* * *}$ & $1371.37^{* * *}$ & $1225.77^{* * *}$ \\
\hline R2 & 0.882 & 0.842 & 0.752 & 0.675 & 0.871 & 0.819 \\
\hline
\end{tabular}

$P$ values are shown in parentheses. Clustered standard errors at the city level are reported, R-squared (within) is reported for FE and centered for IV-2SLS

$* * * * *$, and ${ }^{*}$, significance at $1 \%, 5 \%$, and $10 \%$ levels, respectively

Table 5 Endogeneity test results

\begin{tabular}{|c|c|c|c|c|c|}
\hline \multicolumn{2}{|c|}{ Model $1\left(F D_{(D)}\right)$} & \multicolumn{2}{|c|}{ Model $2\left(\mathrm{FD}_{(\mathrm{A})}\right)$} & \multicolumn{2}{|c|}{ Model $3\left(F D_{(s)}\right)$} \\
\hline Chi-sq (1) & $P$ value & Chi-sq (1) & $P$ value & Chi-sq (1) & $P$ value \\
\hline $12.404^{* * *}$ & 0.0004 & $12.203^{* * *}$ & 0.0005 & $6.108^{* *}$ & 0.0135 \\
\hline
\end{tabular}

$\mathrm{H}_{0}$ specified endogenous regressors can be treated as exogenous

***Significance at the $1 \%$ level

Table 6 Weak identification test: Anderson canon. Corr. LM statistic

\begin{tabular}{lcc}
\hline LM statistic & $P$ value & Outcome \\
\hline $143.125^{* * *}$ & 0.0000 & Reject $\mathrm{H}_{0}$
\end{tabular}

$\mathrm{H}_{0}$ - the model is underidentified

***Significance at the $1 \%$ level

\section{Underidentification test results}

To assess whether the equation is underidentified, we conduct the test for underidentification and weak identification. The null hypothesis that the model is underidentified is strongly rejected at the 1\% level of significance. Test results are presented in Table 6 and apply to all three models.

\section{Weak instruments test results}

The weak identification test shows that our instruments have good explanatory power for the endogenous regressor. The Cragg-Donald Wald F statistic is larger than the Stock-Yogo weak ID test critical values generated, validating the appropriateness of 
Table 7 Weak instrument test results

\begin{tabular}{lr}
\hline Cragg-Donald Wald F statistic & 78.001 \\
Stock-Yogo weak ID test critical values & \\
$10 \%$ Maximal IV size & 19.93 \\
$15 \%$ Maximal IV size & 11.59 \\
$20 \%$ Maximal IV size & 8.75 \\
$25 \%$ Maximal IV size & 7.25
\end{tabular}

$\mathrm{H}_{0}$ weak instruments. Outcome rejects $\mathrm{H}_{0}$

Table 8 Sargan test results

\begin{tabular}{|c|c|c|c|c|c|}
\hline \multicolumn{2}{|l|}{ Model $1\left(\mathrm{FD}_{(\mathrm{D})}\right)$} & \multicolumn{2}{|l|}{ Model $2\left(\mathrm{FD}_{(\mathrm{A})}\right)$} & \multicolumn{2}{|l|}{ Model $3\left(\mathrm{FD}_{(\mathrm{s})}\right)$} \\
\hline Sargan statistic & $P$ value & Sargan statistic & $P$ value & Sargan statistic & $P$ value \\
\hline 0.916 & 0.3385 & 0.078 & 0.7800 & 3.340 & 0.0676 \\
\hline
\end{tabular}

$\mathrm{H}_{0}$ instruments are valid (fail to reject $\mathrm{H}_{0}$ ) at the $1 \%$ and $5 \%$ levels, respectively

our selected instruments. Results of the test are shown in Table 7 and apply to all three models.

\section{Sargan-Hansen test results}

To test our instruments' validity, we conduct the Sargan-Hansen test of overidentifying restrictions under the null hypothesis that our instruments are valid. This means that instruments are uncorrelated with the residuals and can be left out of the model. The results given in Table 8 fail to reject $\mathrm{H}_{0}$ at the $5 \%$ level of significance for all three models.

\section{Influence of fintech on financial development}

The estimation results show that fintech has a significant positive impact on all three dimensions of financial development, with the largest impact on financial access, which has a coefficient of 0.757 . In other words, the model shows that a $10 \%$ increase in fintech development will enhance financial access (measured by the loan balances at financial institutions) by 7.5\%. This indicates that the rapid growth in China's fintech sector has been a substantial driving force for both financial inclusion and access. The coefficients for financial depth and stability are 0.450 and 0.437 , respectively, and all are significant at $1 \%$. Results show that the emergence of fintech has enabled financial institutions in China to attract more deposits and savings from consumers in both rural and urban areas, which can be attributed to synergies between traditional banks and fintech service providers. Another likely contributing factor is that traditional financial service providers are investing heavily in their own digital transformations and fintech subsidiaries.

\section{Regtech and financial development}

The regtech variable, which captures the deployment of fintech in financial regulation, is significantly positive for all the three dimensions of financial development studied. Regtech has the largest impact on financial access, with a coefficient of 0.455 , which is significant at $1 \%$. The coefficients for financial depth (0.223) and stability $(0.163)$ are significant at $1 \%$ and $5 \%$, respectively. This shows that while fintech presents new 
dimensions of risk to financial markets, it can also be employed to mitigate those risks, such as the risk associated with subprime lending that is now being mitigated by regtech. Using regtech, regulators can obtain more complete data on financial markets. By leveraging advances in artificial intelligence (machine learning) algorithms, better insights can be obtained from big datasets that can help make policy decisions more targeted and effective. China is advancing the application of regtech more so than in many other countries, which can be attributed to fewer privacy laws, advances in big data analytics, cloud computing, and artificial intelligence.

\section{Financial openness and industrialization}

Control variables that capture financial openness and the level of industrialization have significant negative coefficients for the depth and stability dimensions of financial development. During the period studied, China has been gradually opening its financial industry to foreign entities; however, this access remains extremely limited. As China transitions to a more consumption-driven economy, the impact of this shift on financial development is unclear. However, greater financial openness is expected to attract more foreign investment and leads to a more developed financial industry, albeit one that is more sensitive to global shocks.

\section{Robustness tests}

To ensure the robustness of our results, we investigate how fintech affects financial access in China at the provincial level, adopting a similar approach to our city-level analysis. The following econometric models are used for our provincial analysis.

$$
\begin{aligned}
F D_{(A)_{j, t}}= & \alpha_{0}+\alpha_{1} \text { Fintech }_{j, t-1}+\alpha_{c} \text { Control }_{j, t-1}+\eta_{t}+\lambda_{j}+\varepsilon_{j, t} \\
F D_{(A)_{j, t}=}= & \alpha_{0}+\alpha_{1} \text { Fintech }_{j, t-1}+\alpha_{2} \text { Finreg }_{j, t-1}+\alpha_{3} \text { Fintech }_{j, t-1} \times \text { Finreg }_{j, t-1} \\
& +\alpha_{c} \text { Control }_{j, t-1}+\eta_{t}+\lambda_{j}+\varepsilon_{j, t}
\end{aligned}
$$

Because of limitations with respect to data availability, the base model was adjusted to include additional control variables, namely, GDP growth rate (GDPgr), trade openness $(T O P)$, and urbanization $(U r b)$. Endogeneity tests confirm that fintech is an endogenous

Table 9 Provincial data summary statistics

\begin{tabular}{llcccc}
\hline Variable & Obs & Mean & Std. Dev & Min & Max \\
\hline$F D_{(A)}$ & 248 & 19.112 & 0.926 & 15.224 & 21.096 \\
Fintech & 248 & 4.677 & 1.038 & 1.345 & 5.819 \\
Finreg & 248 & 10.863 & 1.248 & 4.605 & 14.286 \\
GDPgr & 248 & 9.780 & 2.834 & -2.5 & 17.4 \\
TOP & 248 & 0.282 & 0.329 & 0.017 & 1.587 \\
IND & 248 & 45.531 & 8.435 & 19.01 & 59 \\
Urb & 248 & 55.003 & 13.612 & 22.67 & 89.6 \\
Ipr & 248 & 0.462 & 0.128 & 0.213 & 0.797 \\
Mkt & 248 & 6.210 & 2.131 & -0.23 & 10.13 \\
\hline
\end{tabular}


regressor, so we employ internet penetration rate (Ipr) and provincial marketization $(M k t)$ as instruments. Summary statistics for the provincial data are given in Table 9.

We use data from China's 31 provinces over the same period in the city-level analysis. Post-estimation tests confirm the validity, relevance, and explanatory power of the instruments employed for Eq. (11). However, these instruments prove to have weak explanatory power for the specification shown in Eq. (12) based on Stock-Yogo's weak ID test critical values. Estimation results of both fixed effects with clustered standard errors $\left(\mu_{\mathrm{i}, \mathrm{t}}=\vartheta_{\mathrm{i}, \mathrm{t}}+\varepsilon_{\mathrm{i}, \mathrm{t}}\right)$ and an IV-2SLS panel regression are reported in Table 10.

Estimation results show that fintech development positively impacts financial access at the provincial level, with a coefficient of 0.219 that is significant at $1 \%$. While the regtech coefficient is significant in the IV-2SLS results of model B, weak instrument test results cast doubt on the accuracy of the model parameters. The various provinces have significant disparities in the level of fintech development and in the deployment of regtech. This is largely consistent with the outcome seen at the city level, indicating the robustness of our research results.

\section{Impact of interest rate liberalization on financial development}

Using city-level data and the D-I-D estimator given in Eq. (3), we investigate the impact of China's interest rate liberalization policy on the three dimensions of financial development. The policy was implemented in July 2013 and signified an important milestone in China's gradual path to financial liberalization. D-I-D estimation results are reported in Table 11.

Table 10 Provincial-level analysis: fintech and financial access. Criterion $\left(F D_{(A)}\right)$

\begin{tabular}{|c|c|c|c|c|}
\hline \multirow[t]{2}{*}{ Variables } & \multicolumn{2}{|l|}{ Model A } & \multicolumn{2}{|l|}{ Model B } \\
\hline & $\mathrm{FE}$ & IV-2SLS & $\mathrm{FE}$ & IV-2SLS \\
\hline Fintech $_{j, t-1}$ & $\begin{array}{l}0.129^{* * *} \\
(0.004)\end{array}$ & $\begin{array}{l}0.219^{* * *} \\
(0.000)\end{array}$ & $\begin{array}{l}0.137^{* *} \\
(0.020)\end{array}$ & $\begin{array}{l}0.704^{* * *} \\
(0.005)\end{array}$ \\
\hline Finreg $_{j, t-1}$ & & & $\begin{array}{l}0.034 \\
(0.202)\end{array}$ & $\begin{array}{l}0.219^{* * *} \\
(0.009)\end{array}$ \\
\hline Fintech $_{j, t-1} \times$ Finreg $_{j, t-1}$ & & & $\begin{array}{l}-0.001 \\
(0.790)\end{array}$ & $\begin{array}{l}-0.050^{* *} \\
(0.022)\end{array}$ \\
\hline$G D P g r_{j, t-1}$ & $\begin{array}{l}-0.003 \\
(0.772)\end{array}$ & $\begin{array}{l}0.014 \\
(0.109)\end{array}$ & $\begin{array}{l}0.0003 \\
(0.978)\end{array}$ & $\begin{array}{l}0.023^{*} \\
(0.084)\end{array}$ \\
\hline$T O P_{j, t-1}$ & $\begin{array}{l}-0.757^{* * *} \\
(0.000)\end{array}$ & $\begin{array}{l}-0.651^{* * *} \\
(0.000)\end{array}$ & $\begin{array}{l}-0.683^{* * *} \\
(0.000)\end{array}$ & $\begin{array}{l}-0.883^{* * *} \\
(0.000)\end{array}$ \\
\hline$I N D_{j, t-1}$ & $\begin{array}{l}0.0002 \\
(0.979)\end{array}$ & $\begin{array}{l}-0.003 \\
(0.381)\end{array}$ & $\begin{array}{l}-0.003 \\
(0.691)\end{array}$ & $\begin{array}{l}-0.016^{* *} \\
(0.030)\end{array}$ \\
\hline$U r b_{j, t-1}$ & $\begin{array}{l}0.068^{* * *} \\
(0.000)\end{array}$ & $\begin{array}{l}0.050^{* * *} \\
(0.000)\end{array}$ & $\begin{array}{l}0.065^{* * *} \\
(0.000)\end{array}$ & $\begin{array}{l}0.0517^{* * *} \\
(0.000)\end{array}$ \\
\hline \multicolumn{5}{|l|}{ City FE } \\
\hline \multicolumn{5}{|l|}{ Year FE } \\
\hline Observations & 248 & 248 & 248 & 248 \\
\hline F Statistic & $131.40^{* * *}$ & $295.37^{* * *}$ & $105.42^{* * *}$ & $147.63^{* * *}$ \\
\hline$R^{2}$ & 0.887 & 0.873 & 0.891 & 0.819 \\
\hline
\end{tabular}

$P$ values are shown in parentheses. Clustered standard errors at the provincial level are reported. R-square (within) is reported for FE and centered for IV-2SLS

$* * * * *$, and *, significance at the $1 \%, 5 \%$, and $10 \%$ levels, respectively 
Table 11 D-I-D estimation results: Interest rate liberalization and financial development

\begin{tabular}{|c|c|c|c|c|c|c|}
\hline Variables & $\begin{array}{l}(1) \\
\left(F D_{(D)}\right)\end{array}$ & $\begin{array}{l}(2) \\
\left(F D_{(D)}\right)\end{array}$ & $\begin{array}{l}(3) \\
\left(F D_{(S)}\right)\end{array}$ & $\begin{array}{l}(4) \\
\left(F D_{(s)}\right)\end{array}$ & $\begin{array}{l}(5) \\
\left(F D_{(A)}\right)\end{array}$ & $\begin{array}{l}(6) \\
\left(F D_{(A)}\right)\end{array}$ \\
\hline IRL & $\begin{array}{l}0.804^{* * *} \\
(0.000)\end{array}$ & $\begin{array}{l}0.697^{* * *} \\
(0.000)\end{array}$ & $\begin{array}{l}0.799^{* * *} \\
(0.000)\end{array}$ & $\begin{array}{l}0.721^{* * *} \\
(0.000)\end{array}$ & $\begin{array}{l}0.948^{* * *} \\
(0.000)\end{array}$ & $\begin{array}{l}0.843^{* * *} \\
(0.000)\end{array}$ \\
\hline$G D P p c$ & & $\begin{array}{l}0.193^{* * *} \\
(0.000)\end{array}$ & & $\begin{array}{l}0.133^{* * *} \\
(0.000)\end{array}$ & & $\begin{array}{l}0.200^{* * *} \\
(0.000)\end{array}$ \\
\hline IND & & $\begin{array}{l}0.061^{*} \\
(0.056)\end{array}$ & & $\begin{array}{l}0.031 \\
(0.205)\end{array}$ & & $\begin{array}{l}0.157 \\
(0.152)\end{array}$ \\
\hline$F O P$ & & $\begin{array}{l}0.002 \\
(0.706)\end{array}$ & & $\begin{array}{l}-0.002 \\
(0.637)\end{array}$ & & $\begin{array}{l}0.007 \\
(0.379)\end{array}$ \\
\hline Constant & $\begin{array}{l}16.352^{* * *} \\
(0.000)\end{array}$ & $\begin{array}{l}14.161^{* * *} \\
(0.000)\end{array}$ & $\begin{array}{l}15.750^{* * *} \\
(0.000)\end{array}$ & $\begin{array}{l}14.341^{* * *} \\
(0.000)\end{array}$ & $\begin{array}{l}15.844^{* * *} \\
(0.000)\end{array}$ & $\begin{array}{l}13.152^{* * *} \\
(0.000)\end{array}$ \\
\hline Observations & 2,312 & 2,242 & 2,312 & 2,242 & 2,312 & 2,242 \\
\hline R-squared & 0.912 & 0.922 & 0.897 & 0.900 & 0.781 & 0.791 \\
\hline $\begin{array}{l}\text { Number of id } \\
\text { City FE }\end{array}$ & 289 & 282 & 289 & 282 & 289 & 282 \\
\hline Year FE & & & & & & \\
\hline
\end{tabular}

Estimation results indicate that implementing the interest rate liberalization policy has had a significant positive impact on the three dimensions of financial development within China's cities. This shows that China's gradual financial liberalization is likely to promote continued financial development.

\section{Conclusions and a policy framework for fintech regulation}

China's fintech industry has proliferated during the period reviewed by this study. Analysts estimate that the sector will continue to maintain positive momentum while becoming more mature and consolidated (Ernst and Young 2019). Regulators have been trying to find the optimal balance between fostering fintech growth and managing the risks that it presents. This study can assist in that effort by providing a better understanding of the relationship between fintech and dimensions of financial development.

Is fintech a complement to or a substitute for financial development? Although more rigorous analytical work is needed to answer this question conclusively, the results of this study show a positive causal relationship between fintech and various aspects of financial development. This is especially important for emerging markets in developing a robust fintech policy framework. Figure 2 highlights some of the key facets of a robust fintech regulatory framework.

\section{Policy recommendations}

By understanding the relationship between fintech and financial development, regulators can formulate better policies to promote fintech growth while preserving financial system stability. Assessing the implications of new and emerging technologies 


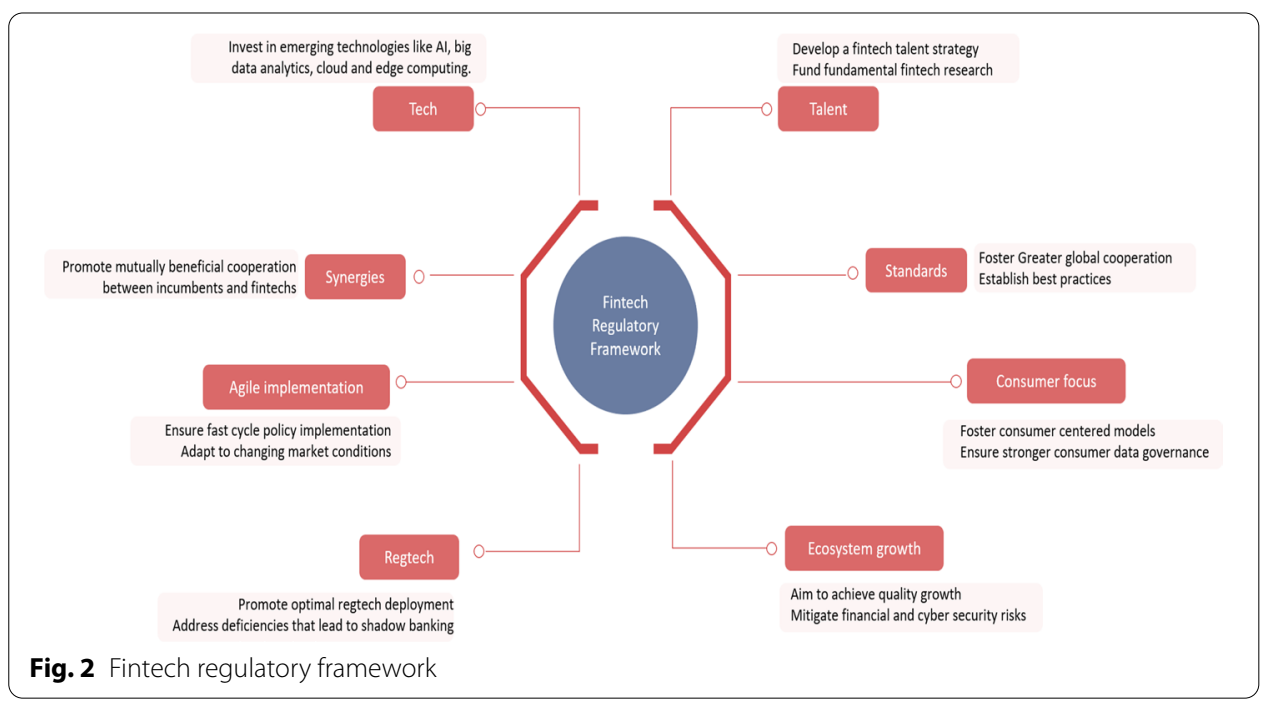

such as artificial intelligence, big data analytics, cloud computing, machine learning, blockchain, 5G, the Internet of Things, biometrics, and other technologies that support fintech can help regulators to cope with the pace of fintech growth. Regtech can allow financial institutions and fintech companies to help maintain financial stability and mitigate risks associated with digital financial services. Although the following is not fully grounded in the empirical findings of this study, outline the following recommendations for fintech regulation in China and other emerging markets.

1. Accelerate the formulation and implementation of fintech industry regulatory frameworks.

2. Foster greater cooperation with global regulators in the field of fintech.

3. Embrace regtech and leverage emerging technologies to help regulate the digital financial service industry.

4. Assist traditional banks on their path to digital transformation.

5. Promote mutually beneficial cooperation between traditional financial institutions and fintech players, particularly in the field of financial intelligence, to minimize risks and promote quality growth.

6. Invest in artificial intelligence and big data analytics to promote financial system stability.

7. Strengthen fintech services that cater to underserved market segments and foster cooperation with incumbent banks.

8. Address deficiencies in the financial service industry that facilitate the rise of shadow banking practices.

9. Strengthen fundamental research in emerging technologies that promotes fintech sector growth and develop a comprehensive talent strategy for the fintech industry based on sustainable and ethical practices. 
10. Create research institutions on fintech development and invest in global cooperation to promote quality research.

\section{Conclusions}

Our findings add to the existing literature on fintech's role in promoting financial access and inclusion and offer several policy implications. First, regulators should develop and implement a comprehensive policy framework to promote balanced fintech sector growth. Second, policymakers should develop strategies for optimally deploying regtech to mitigate risks associated with the fintech sector. Third, our study findings show that financial development can be attained through active policy initiatives aimed at financial liberalization. Last, the regulatory framework suggested by this study offers policymakers in emerging markets key areas to prioritize as they grapple with the rapid rise of fintech.

This study is not without its limitations. First, the lack of data hindered the scope of the econometric analysis. Second, China's unique internet infrastructure limits the generalizability of findings. Although China's fintech growth has occurred in the context of a unique internet ecosystem and other idiosyncratic factors, this study still provides vital lessons for other developing countries looking to foster financial development through fintech innovations.

\section{Further research direction}

The role of fintech in promoting financial inclusivity has strong theoretical foundations (Gabor and Brooks 2016; Hasan et al. 2020); however, empirical research on fintech is still in its infancy. This is one of the few empirical studies to highlight the positive role fintech plays in supporting financial development. There is a need for more empirical research on how fintech impacts all relevant dimensions of financial development. It is imperative for researchers to critically map the risks fintech poses to existing financial systems to help inform better regulatory approaches. As fintech continues to disrupt the global financial landscape, future research should also focus on its role beyond inclusion and how it can be used to help developing countries achieve sustainable financial development and stability.

\section{Appendix A}

See Table 12. 
Table 12 List of acronyms

\begin{tabular}{ll}
\hline Term & Description \\
\hline D-I-D & Difference-in-differences \\
Fintech & Financial technology \\
Regtech & Regulatory technology \\
Insurtech & Insurance technology \\
PE & Private equity \\
VC & Venture capital \\
IOT & Internet of things \\
MMF & Money market fund \\
ICT & Information communication technology \\
IOT & Internet of things \\
GDP & Gross domestic product \\
WTO & World trade organization \\
DFS & Digital financial services \\
PKU-DFIC & Peking university-digital financial inclu- \\
IV & sion index of china \\
\hline
\end{tabular}

\section{Appendix B}

See Table 13.

Table 13 Provincial analysis post estimation test results

\begin{tabular}{|c|c|c|c|}
\hline \multicolumn{2}{|l|}{ Model A } & \multicolumn{2}{|l|}{ Model B } \\
\hline Chi-sq (1) & $P$ value & Chi-sq (1) & $P$ value \\
\hline \multicolumn{4}{|c|}{ Endogeneity test results ${ }^{1}$} \\
\hline $12.967^{* * *}$ & 0.0003 & $8.921 * * *$ & 0.0028 \\
\hline \multicolumn{2}{|l|}{ Model A } & \multicolumn{2}{|l|}{ Model B } \\
\hline Sargan statistic & $P$ value & Sargan statistic & $P$ value \\
\hline \multicolumn{4}{|c|}{ Sargan test for valid instruments $^{2}$} \\
\hline 0.383 & 0.5357 & 1.680 & 0.1950 \\
\hline \multicolumn{2}{|l|}{ Model A } & \multicolumn{2}{|l|}{ Model B } \\
\hline LM statistic & $P$ value & LM statistic & $P$ value \\
\hline \multicolumn{4}{|c|}{ Underidentification test results ${ }^{3}$} \\
\hline $72.085^{* * *}$ & 0.0000 & $12.763^{* * *}$ & 0.0017 \\
\hline
\end{tabular}

${ }^{1} \mathrm{H}_{0}$ specified endogenous regressors can be treated as exogenous and ${ }^{* * *}$ indicates significance at the $1 \%$ level

${ }^{2} \mathrm{H}_{0}$ Instruments are valid, fail to reject $\mathrm{H}_{0}$ at the $1 \%$ and $5 \%$ level, respectively.

${ }^{3} \mathrm{H}_{0}$ the model is underidentified, and ${ }^{* * *}$ indicates significance at the $1 \%$ level 


\section{Authors' contributions}

All authors read and approved the final manuscript.

\section{Funding}

The financial assistance provided by the National Natural Science Foundation of China (71774071), the National Statistical Science Research Project (2021LY055); Jiangsu Soft Science Research Project (BR2021030); Zhenjiang Soft Science Research Project (RK2021010); and the Key Academic Research Project of Jiaxing University (ICCPR2021007) is highly appreciated by researchers of this study.

\section{Declarations}

\section{Competing interests}

The authors declare that they have no competing interests

\section{Author details}

${ }^{1}$ School of Economics, Shanghai University, Shanghai 200240, China. ${ }^{2}$ School of Economics and Management, Hebei University of Technology, Tianjin 300401, China. ${ }^{3}$ School of Finance and Economics, Division of Low-carbon Economy and Environment Regulation, Institute of Industrial Economics, Jiangsu University, Zhenjiang 212013, Jiangsu, China. ${ }^{4}$ School of Economics and Management, Tongji University, Shanghai, China. ${ }^{5}$ Tokai University, 4-1-1 Kitakaname, Hiratsuka-shi, Kanagawa 259-1292, Japan.

Received: 4 November 2020 Accepted: 14 November 2021

Published online: 28 January 2022

\section{References}

Accenture (2018) Mind the gap: the challenges to fintech adaption. In: FinTech Innovation Lab. Accenture Akçay S (2019) Remittances and financial development in Bangladesh: substitutes or complements? Appl Econ Lett 27:1206-1214

Anagnostopoulos I (2018) Fintech and regtech: Impact on regulators and banks. J Econ Bus 100:7-25

Ansari S, Krop P (2012) Incumbent performance in the face of a radical innovation: towards a framework for incumbent challenger dynamics. SSRN Electron J 41:1357-1374

Berger AN, Bouwman CHS, Kim D (2017) Small bank comparative advantages in alleviating financial constraints and providing liquidity insurance over time. Rev Financ Stud 30:3416-3454

Breusch T, Pagan A (1980) The lagrange multiplier test and its application to model specification in econometrics. Rev Econ Stud 47:239-253

Christensen CM (2016) The innovator's dilemma: when new technologies cause great firms to fail. Harvard Business Review Press, Brighton

Cole RA, Cumming DJ, Taylor JR (2019) Does FinTech compete with or complement bank finance? https://ssrn.com/ abstract $=3302975$

Dabla-Norris E, Srivisal N (2013) Revisiting the link between finance and macroeconomic volatility. IFM Working paper 13/29:

Diemers D, Lamaa A, Salamat J, Steffens T (2015) Developing a FinTech ecocystem in the GCC. In: Strategy\&, p. 16. PWC

Ding D, Chong G, Lee Kuo Chuen D, Cheng TL (2018) From Ant Financial to Alibaba's rural Taobao strategy-how Fintech is transforming social inclusion. In: Lee D, Deng RH (eds) Handbook of blockchain, digital finance, and inclusion, vol 1. Academic Press, Cambridge, pp 19-35

Dobson W, Westland T (2018) Financial liberalisation and trade: an examination of moving up value chainsin the AsiaPacific region. In: Armstrong S, Westland T (eds) Asian economic integration in an era of global uncertainty. ANU Press, Canberra

Drasch BJ, Schweizer A, Urbach N (2018) Integrating the 'Troublemakers': a taxonomy for cooperation between banks and fintechs. J Econ Bus 100:26-42

Drummer D, Jerenz A, Siebelt P, Thaten M (2016) Fintech—challenges and opportunities. How digitization is transforming the financial sector. McKinsey \& Company, Chicago

Ernst, Young (2019) EY 2019 global fintech adoption index

Gabor D, Brooks S (2016) The digital revolution in financial inclusion: international development in the fintech era. New Polit Econ 22:423-436

Goode A (2018) Biometrics for banking best practices and barriers to adoption. Biometric Technol Today 2018:5-7

Gopalan S, Sasidharan S (2020) Financial liberalization and access to credit in emerging and developing economies: a firm-level empirical investigation. J Econ Bus 107:105861

Guo F, Wang JY, Wang F, Kong T, Zhang X, Cheng ZY (2019) Measuring the development of digital financial inclusion in China: index compilation and spatial characteristics. China Econ Q 19:1401-1418

Haddad C, Hornuf L (2018) The emergence of the global fintech market: economic and technological determinants. Small Bus Econ 53:81-105

Hasan I, Wachtel P, Zhou M (2009) Institutional development, financial deepening and economic growth: evidence from China. J Bank Finance 33:157-170

Hasan MM, Yajuan L, Mahmud A (2020) Regional development of china's inclusive finance through financial technology. SAGE Open 10:2158244019901252 
Huang Y, Ji Y (2017) How will financial liberalization change the Chinese economy? Lessons from middle-income countries. J Asian Econ 50:27-45

Insights C (2019) Global Fintech Report Q2 2019. CB Insights

Jagtiani J, Lemieux C (2018) Do fintech lenders penetrate areas that are underserved by traditional banks? J Econ Bus 100:43-54

Jian C, Hu S (2020) Interaction between Banks and Enterprises in the Process of interest rate Liberalization - from the perspective of listed companies' purchase of bank financial products. China Ind Econ 6:155-173

Jiang D, Li W, Shen Y, Yao Z (2020) Market liberalization and tax avoidance: evidence from the Shanghai-Hong Kong stock connect program in China. Econ Syst 44:100811

Lee I, Shin YJ (2018) Fintech: ecosystem, business models, investment decisions, and challenges. Bus Horizons 61:35-46

Lee C-C, Lin C-W, Zeng J-H (2016) Financial liberalization, insurance market, and the likelihood of financial crises. J Int Money Finance 62:25-51

Leong C, Tan B, Xiao X, Tan FTC, Sun Y (2017) Nurturing a FinTech ecosystem: the case of a youth microloan startup in China. Int J Inform Manag 37:92-97

Levine R (2005) Chapter 12 finance and growth: theory and evidence. In: Aghion P, Durlauf S (eds) Handbook of economic growth. Elsevier, Amsterdam, pp 865-934

Li GZ, Xiong DH, Liu L (2016) How does SMBs' development affect SMEs' financing. J Finance Res 12:78-94

Li H, Tao Q, Xiao H, Li G (2019) Money market funds, bank loans and interest rate liberalization: evidence from an emerging market. Finance Res Lett 30:426-435

Mahoney J (2019) The rise of Chinese fintech: lessons for the United States. Colombia Business School, New York

Makina D (2019) The potential of FinTech in enabling financial inclusion. In: Makina D (ed) Extending financial inclusion in Africa. Academic Press, Cambridge, pp 299-318

Meijering E (2002) A chronology of interpolation: from ancient astronomy to modern signal and image processing. Proc IEEE 90:319-342

Min Z, Weidong C, Jingtong Z, Xinzhe G, Qiyue X (2018) The development of China's financial system: a global perspective. China Econ J 11:25-43

Muganyi T, Linnan Y, Sun H (2021) Green finance, fintech and environmental protection: evidence from China. Environ Sci Ecotechnol 7:100107

Nicoletti B (2017) Financial services and fintech. In: B Nicoletti, W Nicoletti, Weis (eds) The Future of FinTech. Springer, Berlin, pp 3-29

Pesaran MH (2014) Testing weak cross-sectional dependence in large panels. Econometr Rev 34:1089-1117

Pesaran M, Yamagata T (2008) Testing slope homogeneity in large panels. J Econometr 142:50-93

Pesaran, MH (2004) General diagnostic tests for cross section dependence in panels. In: Cambridge working papers in economics. University of Cambridge, Faculty of Economics, Cambridge

PWC (2019) How Fintech is shaping China's financial services? PWC China, Chengdu

Rajan RG, Zingales $L$ (2003) The great reversals: the politics of financial development in the twentieth century. J Financ Econ $69: 5-50$

Ryan RM, O'Toole CM, McCann F (2014) Does bank market power affect SME financing constraints? J Bank Finance 49:495-505

Sahay MR, Cihak MM, N'Diaye MP, Barajas MA, Kyobe MA, Mitra MS, Mooi MN, Yousefi MR (2015) Rethinking financial deepening: stability and growth in emerging markets. In: SDN. IMF

Salampasis D, Mention A-L (2018) FinTech: harnessing innovation for financial inclusion. In: Chuen DL, Deng RH (eds) Handbook of blockchain, digital finance, and inclusion, vol 2. Academic Press, Cambridge, pp 451-461

Sarafidis V, Wansbeek T (2011) Cross-sectional dependence in panel data analysis. Econometr Rev 31:483-531

Shahbaz M, Bhattacharya M, Mahalik MK (2017) Financial development, industrialization, the role of institutions and government: a comparative analysis between India and China. Appl Econ 50:1952-1977

Sheng T (2020) The effect of fintech on banks' credit provision to SMEs: evidence from China. Finance Res Lett 39:101558

Sun H, Kporsu AK, Taghizadeh-Hesary F, Edziah BK (2020a) Estimating environmental efficiency and convergence: 1980 to 2016. Energy 208:118224

Sun Y, Chen L, Sun H, Taghizadeh-Hesary F (2020b) Low-carbon financial risk factor correlation in the belt and road PPP project. Finance Res Lett 35:101491

Sun H, Muganyi T (2019) Financial depth and international trade: evidence from China. Trans Corpor Rev 11:346-359

Sun H, Edziah BK, Kporsu AK, Sarkodie SA, Taghizadeh-Hesary F (2021) Energy efficiency: the role of technological innovation and knowledge spillover. Technol Forecast Soc Change 167:120659. https://doi.org/10.1016/j.techfore.2021. 120659

Svirydzenka, K (2016) Introducing a new broad-based index of financial development. IFM Working paper

Tianhong (2019) http://www.thfund.com.cn/en/about.html

Wang Y, Li X, Abdou HA, Collins GN (2015) Financial development and economic growth in China. Invest Manag Financ Innov 13:8-18

Wharton (2019) Fintech in China: what lies ahead. https://knowledge.wharton.upenn.edu/article/finte ch-china-lies-ahead/

Wooldridge JM (2010) Econometric analysis of cross section and panel data. The MIT Press, Cambridge

WorldBank (2018) Global Financial Inclusion (Global Findex) Database. https://www.worldbank.org/en/publication/gfdr/ data/global-financial-development-database

Xiao X, Zhang L, Wang Y, Huang C (2017) China's path to FinTech development. Eur Econ 2:143-159

Yin W, Kirkulak-uludag B, Zhang S (2019) Is financial development in China green? Evidence from city level data. J Clean Prod 211:247-256

Yiping H, Qin G, Xun W (2014) Financial liberalization and the middle-income trap. China Econ Rev 31:426-440

Yuan H, Zhang T, Feng Y, Liu Y, Ye X (2019) Does financial agglomeration promote the green development in China? A spatial spillover perspective. J Clean Prod 237:117808 
Zaefarian G, Kadile V, Henneberg SC, Leischnig A (2017) Endogeneity bias in marketing research: problem, causes and remedies. Ind Mark Manag 65:39-46

Zhang C, Zhu Y, Lu Z (2015) Trade openness, financial openness, and financial development in China. J Int Money Finance 59:287-309

Zhou W, Arner DW, Buckley RP (2018) Regulating FinTech in China: from permissive to balanced. In: Lee D, Deng RH (eds) Handbook of blockchain, digital finance, and inclusion, vol 2. Academic Press, Cambridge, pp 45-64

\section{Publisher's Note}

Springer Nature remains neutral with regard to jurisdictional claims in published maps and institutional affiliations.

Submit your manuscript to a SpringerOpen ${ }^{\circ}$ journal and benefit from:

- Convenient online submission

- Rigorous peer review

- Open access: articles freely available online

- High visibility within the field

- Retaining the copyright to your article

Submit your next manuscript at $\gg$ springeropen.com 